Hans-Joachim Wilke

Friederike Rohlmann

Cornelia Neidlinger-Wilke

Karin Werner

Lutz Claes

Annette Kettler

\section{Validity and interobserver agreement of a new radiographic grading system for intervertebral disc degeneration: Part I. Lumbar spine}

Published online: 4 May 2006

(c) Springer-Verlag 2006

The online version of the original can be found at http://dx.doi.org/10.1007/s00586005-1029-9

H.-J. Wilke $(\bowtie) \cdot$ F. Rohlmann

C. Neidlinger-Wilke $\cdot$ K. Werner

L. Claes - A. Kettler

Institute for Orthopaedic Research and

Biomechanics, University of Ulm,

Helmholtzstrasse 14, 89081 Ulm, Germany

E-mail: hans-joachim.wilke@uni-ulm.de

\section{Eur Spine J (2005) DOI 10.1007/ \\ s00586-005-1029-9}

An acknowledgement of financial support was omitted:

Acknowledgement: The authors gratefully acknowledge the German Research Council (Deutsche Forschungsgemeinschaft, WI 1352/6-1) for financial support. 